Buddhism and

Christianity in Japan 



\section{Buddhism and Christianity in Japan}

From Conflict to Dialogue, 1854-1899

Notto R. Thelle

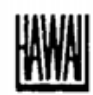


(C) 1987 University of Hawail Press

All Rights Reserved

MANUFACTURED IN THE

United States of America

This book has been published with the help of a grant from the Norwegian Research Council for Science and the Humanities.

\section{Library of Congress Cataloging-in-Publication Data}

Thelle, Notto R., 1941-

Buddhism and Christianity in Japan.

Bibliography: p.

Includes index.

1. Japan-Church history. 2. Missions to

Buddhists-Japan. 3. Christianity and other religions-Buddhism. 4. Buddhism-RelationsChristianity. I. Title.

$\begin{array}{llll}\text { BR1307.T48 } 1987 & \text { 261.2'43’0952 86-16147 }\end{array}$

ISBN 0-8248-1006-6 